\title{
Association of HTRA1 and ARMS2 gene polymorphisms with response to intravitreal ranibizumab among neovascular age-related macular degenerative subjects
}

Nur Afiqah Mohamad ${ }^{1}$, Vasudevan Ramachandran ${ }^{1 *}$, Hazlita Mohd Isa², Yoke Mun Chan ${ }^{1,3}$, Nor Fariza Ngah ${ }^{4}$, Siew Mooi Ching ${ }^{5}$, Fan Kee Hoo ${ }^{6}$, Wan Aliaa Wan Sulaimann, Liyana Najwa Inche Mat ${ }^{6}$ and Mohd Hazmi Mohamed ${ }^{7}$

\begin{abstract}
Background: The association of HTRA1 rs11200638 and ARMS2 rs10490924 gene polymorphisms with response to intravitreal ranibizumab therapy among neovascular AMD (nAMD) subjects in Malaysia was determined in this study, followed by the expression of HTRA1 and ARMS2 genes.

Results: Both single nucleotide polymorphisms (SNPs) recorded a significant association between nAMD and controls with HTRA1 rs 11200638 at $P=0.018(\mathrm{OR}=1.52,95 \% \mathrm{Cl}=1.07-215)$ and ARMS2 rs 10490924 at $P<0.001$ (OR $=2.44,95 \% \mathrm{Cl}=1.75-3.42)$. An association was also observed in response to ranibizumab for both SNPs in a logistic regression analysis $(P<0.001)$. The mRNA levels in the HTRA1 variant between responder and non-responder groups were significantly different for the homozygous non-risk $G G$ genotype $(P=0.032)$.

Conclusions: The HTRA1 rs11200638 and ARMS2 rs10490924 gene polymorphisms are associated with nAMD among Malaysians. Both gene polymorphisms were also correlated with response to intravitreal ranibizumab therapy based on visual and anatomical outcomes especially the HTRA1 rs11200638 variant.
\end{abstract}

Keywords: Age-related macular degeneration, Age-related maculopathy susceptibility 2, High temperature requirement a serine peptidase 1, Polymorphism, Ranibizumab

\section{Background}

Age-related macular degeneration (AMD) is a complex multifactorial disease and a common cause of visual impairment among elderly populations worldwide [1]. The neovascular (or exudative) form of AMD (nAMD) is an advanced form of AMD and responsible for the majority of irreversible vision loss if left untreated. The aetiology of nAMD is multifactorial; both environmental and genetic predispositions are suggested to be involved in nAMD pathogenesis. Advanced age and smoking are the

\footnotetext{
* Correspondence: vasudevan@upm.edu.my; vasuphd@gmail.com ${ }^{1}$ Malaysian Research Institute on Ageing, Universiti Putra Malaysia, 43400 Serdang, Selangor DE, Malaysia

Full list of author information is available at the end of the article
}

strongest modifiable risk factors reported in association with nAMD among Europeans [2,3] and in Asian populations $[4,5]$. In addition to environmental factors, genetics plays a role in the aetiology of nAMD. Age-related maculopathy susceptibility 2 (ARMS2 or LOC387715) and high-temperature requirement $A$ serine peptidase 1 (HTRA1) genes are among the susceptible genes that are well studied in most populations with contradictory findings [6-8].

The ARMS2 and HTRA1 genes are located nearby on the 10q26 chromosome in a strong linkage disequilibrium which could be the main reason for these inconsistent results as most genetic association studies have insufficient data on distinguishing these two genes with nAMD. The

(c) The Author(s). 2019 Open Access This article is distributed under the terms of the Creative Commons Attribution 4.0 International License (http://creativecommons.org/licenses/by/4.0/), which permits unrestricted use, distribution, and 
rs11200638 polymorphism at the promoter region of HTRA1 was suggested to be related to overexpression of the gene among nAMD patients with the minor A allele, which was related to a significantly lower expression of HTRA1 mRNA compared with the major $\mathrm{G}$ allele $[9,10]$. However, Wang et al. showed that there are no significant changes to the HTRA1 rs11200638 and ARMS2 rs104909 24 mRNA levels among AMD [11].

HTRA1 encodes a heat shock serine protease and regulates the transforming growth factor- $\beta$ (TGF- $\beta$ ) which is involved in regulating angiogenesis and extracellular matrix deposition; thus, the overexpression of HTRA1 among nAMD was suggested to be due to the inhibition of TGF- $\beta$ [12]. The ARMS2 gene was shown to encode a function in the mitochondrial outer membrane of the retina; therefore, the rs10490924 polymorphism in the exon 1 region of the ARMS2 gene, which causes a change of alanine to serine amino acid (A69S), may be a genetic factor leading to nAMD by affecting the function of the retinal mitochondria [13].

Vascular endothelial growth factor (VEGF) is also involved in $\mathrm{nAMD}$ development due to formation of angiogenesis and vascular permeability that results in fluid leakage across the blood vessels [1]. It focuses on inhibiting VEGF with an intravitreal injection of anti-VEGF agents such as bevacizumab [14] and ranibizumab [15]. While the anti-VEGF therapy was proved to effectively slow the progress of choroidal neovascularisation (CNV), heterogeneity was observed among patients in terms of degree of response and duration of treatment [16], and it was hypothesised that genetic biomarkers that are strongly associated with nAMD development such as the variants of CFH, VEGFA, ARMS2 and HTRA1 genes might be involved in this heterogeneous response [17-20].

Furthermore, pharmacogenetic studies have been increasing to further investigate the varied response to ranibizumab anti-VEGF therapy, especially between high-risk polymorphisms associated with nAMD such as the rs11200638 polymorphism in HTRA1 gene [6, 21] and rs10490924 polymorphism in ARMS2 gene [7]. Studies have reported the risk allele of the HTRA1 gene could lead to overexpression of HTRA1 protein and possibly affecting the integrity of Bruch's membrane and stimulate the development of CNV [9]. The inhibition of TGF- $\beta$ by HTRA1 could also influence the response to anti-VEGF inhibitors as TGF- $\beta$ plays an important role in angiogenesis [22]. Regarding the expression of $A R M S 2$ in the mitochondrial retina, evidence has suggested that variants of the ARMS2 gene could lead to RPE dysfunction due to mitochondrial DNA damage that accumulates in the retina and RPE. Furthermore, the mitochondria are known to be a major source of superoxide anion in the cell, indicating damages to the mitochondria leads to oxidative stress in
nAMD which possibly could affect the response to anti-VEGF inhibitors [22].

However, the current research is inconclusive as there are conflicting findings on the association of rs11200638 and rs10490924 gene polymorphisms in response to ranibizumab therapy $[16,23]$. This has led us to evaluate the genetic association of rs11200638 polymorphism in the HTRA1 gene and rs10490924 polymorphism in the $A R M S 2$ gene and its responses to ranibizumab therapy among nAMD subjects in Malaysia. We also investigated the correlation between HTRA1 and ARMS2 mRNA levels among the subjects responding and not responding to ranibizumab therapy.

\section{Results}

\section{Sample characteristics}

The subjects' socio-demographic characteristics are presented in Table 1. From 145 nAMD subjects and 145 control subjects, nAMD subjects recorded a significantly higher age $(69.10 \pm 7.51$ years $)$ compared to controls $(64.96 \pm 10.12$ years, $P<0.001)$. Male subjects were recorded with significantly greater frequency $(P=0.019)$ in both nAMD (59.3\%) and controls (72.4\%) compared to female subjects in both groups.

A comparison between ethnicities revealed that Chinese subjects were highest in the nAMD group (60.7\%); however, among the controls, Malay subjects were reported highest (41.4\%). The co-morbidities that reported a significant difference between $\mathrm{nAMD}$ and control was hypertension $(P=0.002)$ whereby nAMD had a higher frequency of hypertensive subjects $(62.1 \%)$ compared to controls $(44.1 \%)$. Smoking was also observed to be significantly associated with nAMD compared to controls $(P<0.001)$.

\section{Genotypic and allelic association among nAMD and control subjects}

Genotyping was performed for both ARMS2 rs10490924 and HTRA1 rs11200638 gene polymorphisms (Fig. 1a, b) and compared between nAMD and control subjects. Genotyping data showed that allelic frequencies were in Hardy-Weinberg equilibrium $(P>0.05)$ except for the nAMD group in HTRA1 rs11200638 $(P<0.05)$. Both gene polymorphisms showed a significant difference for genotypes and alleles when compared between the two subject groups with a recorded $\mathrm{OR}=2.44, \mathrm{CI}=1.75-$ $3.42(P<0.001)$ for the ARMS2 rs10490924 polymorphism and $\mathrm{OR}=1.52, \mathrm{CI}=1.07-2.15(P=0.018)$ for the HTRA1 rs11200638 polymorphism (Table 2). A strong linkage disequilibrium is recorded between the two polymorphisms $\left(D^{\prime}=0.92, r^{2}=0.68\right)$, suggesting the nearly identical association test and odd ratios.

Further genetic association analysis was performed between the genotypes of both gene polymorphism with 
Table 1 Socio-demographic characteristic of subjects

\begin{tabular}{lllll}
\hline Parameter & & nAMD $(n=145)$ & Controls $(n=145)$ & $P$ value \\
\hline Age & Male & $69.10 \pm 7.51$ & $64.96 \pm 10.12$ & $<0.001^{b_{*}}$ \\
Gender & Female & $86(59.3)$ & $105(72.4)$ & $40(27.6)$ \\
Mace & Malay & $59(40.7)$ & $60(41.4)$ & $0.019^{*}$ \\
& Chinese & $51(35.2)$ & $58(40.0)$ & $27(18.6)$ \\
Indian & $88(60.7)$ & $57(39.3)$ & 0.221 \\
Co-morbidities & DM & $6(4.1)$ & $64(44.1)$ & $0.002^{*}$ \\
& HPT & $47(32.4)$ & $36(24.8)$ & 0.593 \\
Smoking & DM + HPT & $40(62.1)$ & $24(16.6)$ & $<0.001^{*}$ \\
\hline
\end{tabular}

Data are presented as percentages in parentheses

DM diabetes mellitus, HPT hypertension

*Significant $P$ value, $P<0.05$

${ }^{\text {a }}$ Chi-square test

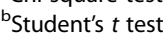

BCVA and CRT of nAMD patients at baseline and 3 and 6 months post-treatment with intravitreal ranibizumab therapy (Table 3). Both homozygous risk genotypes of ARMS2 rs10490924 and HTRA1 rs11200638 showed a significantly worse mean BCVA and mean CRT at 6 months post-treatment with mean BCVA $0.62 \pm 0.28$ logMAR $(P$ $=0.046)$ and $0.61 \pm 0.29 \log$ MAR $(P=0.044)$, respectively, and mean CRT $400.1 \pm 127.90 \mu \mathrm{M}(P<0.001)$ and $387.5 \pm$ $129.89 \mu \mathrm{M}(P=0.008)$, respectively. These findings were supported by the mean changes of BCVA and CRT from the baseline, which also reported significantly worse changes $(P<0.05)$ at 6 months post-treatment for both homozygous risk genotypes in both polymorphisms. In addition, male nAMD subjects were significantly frequent carrying the risk genotype compared to females for both ARMS2 rs10490924 (56.7\%, $P=0.032)$ and HTRA1 rs11200638 $(54.4 \%, P=0.001)$.

\section{Comparison of response to treatment}

The nAMD subjects were further classified into responders and non-responders to the intravitreal ranibizumab therapy based on the BCVA and CRT recorded

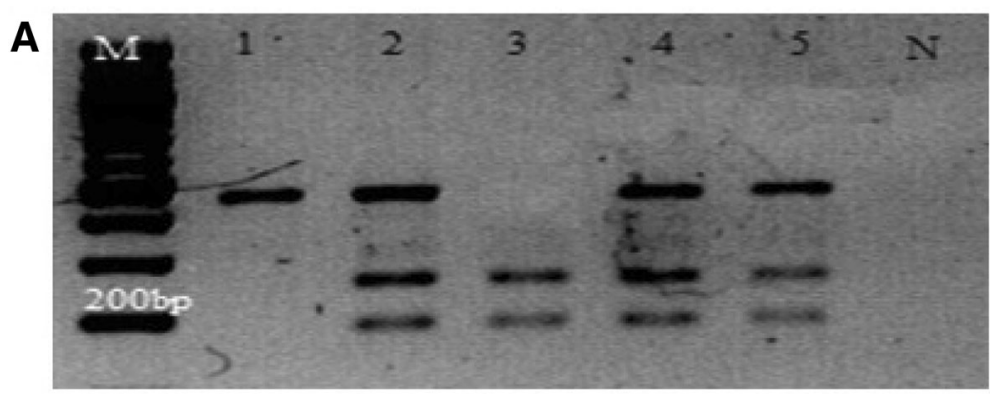

B

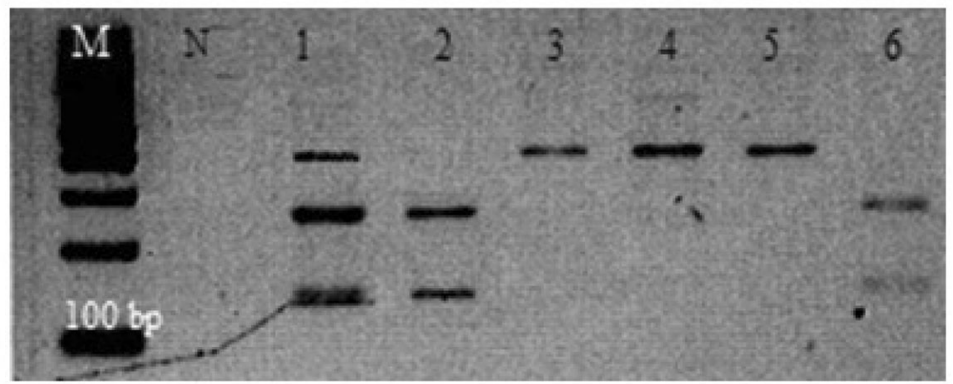

Fig. 1 PCR and RFLP product for ARMS2 rs10490924 (a) and HTRA1 rs11200638 (b) gene polymorphisms on 2\% agarose gel. RFLP product of ARMS2 rs10490924 (a): Lane 1 shows homozygous GG, 259 bp and 190 bp; lane 2 and lane 6 show heterozygous GT, 449 bp, 259 bp and 190 bp; lane 3 until lane 5 show homozygous T, 449 bp. RFLP product of HTRA1 rs11200638 (b): lane 1, lane 4, lane 5 and lane 6 show homozygous AA, 385 bp; lane 2 shows heterozygous GA, 385 bp, 246 bp and 139 bp; lane 7 shows homozygous GG, 246 bp and 139 bp 
Table 2 Genotype association between subjects

\begin{tabular}{|c|c|c|c|c|c|c|c|c|c|c|c|c|}
\hline \multirow[t]{2}{*}{ Gene variant } & \multirow[t]{2}{*}{ W/M } & \multirow[t]{2}{*}{ Subjects } & \multirow[t]{2}{*}{ WW } & \multirow[t]{2}{*}{ WM } & \multirow[t]{2}{*}{ MM } & \multirow[t]{2}{*}{$P$ value $^{a}$} & \multirow[t]{2}{*}{ W (\%) } & \multirow[t]{2}{*}{ M (\%) } & \multirow[t]{2}{*}{$P$ value $^{a}$} & \multicolumn{2}{|l|}{ HWE $^{\mathrm{b}}$} & \multirow[t]{2}{*}{ OR $(95 \% \mathrm{Cl})$} \\
\hline & & & & & & & & & & $x^{2}$ & $P$ & \\
\hline \multirow[t]{2}{*}{ ARMS2 rs10490924 } & $\mathrm{G} / \mathrm{T}$ & nAMD & $21(14.5)$ & $57(39.3)$ & $67(46.2)$ & & 34.1 & 65.9 & & 2.293 & 0.318 & 2.44 \\
\hline & & Controls & $46(31.7)$ & $70(48.3)$ & $29(20.0)$ & $<0.001^{*}$ & 55.9 & 44.1 & $<0.001^{*}$ & 0.068 & 0.966 & $(1.75-3.42)$ \\
\hline \multirow[t]{2}{*}{ HTRA1 rs11200638 } & $\mathrm{G} / \mathrm{A}$ & nAMD & 19 (13.1) & $47(32.4)$ & $79(54.5)$ & & 29.3 & 70.7 & & 6.823 & 0.033 & 1.52 \\
\hline & & Controls & 15 (10.3) & $82(56.6)$ & $48(33.1)$ & $<0.001^{*}$ & 38.6 & 61.4 & $0.018^{*}$ & 5.386 & 0.068 & $(1.07-2.15)$ \\
\hline
\end{tabular}

Data are presented as percentages in parentheses

$M$ risk allele, $W$ non-risk allele, $O R$ odds ratio, $C I$ confidence interval, $H W E$ Hardy-Weinberg equilibrium

*Significant $P$ value, $P<0.05$

${ }^{a}$ Chi-square test

${ }^{b}{ }^{2}$ goodness-of-fit test

after treatment. Overall, responders recorded a worse mean BCVA $(0.66 \pm 0.27 \operatorname{logMAR}, P=0.001)$ and worse mean CRT $(480.3 \pm 153.78 \mu \mathrm{M}, P<0.001)$ at baseline compared to non-responders. However, at 6 months post-treatment, non-responders recorded a worse mean BCVA $(0.67 \pm 0.28 \operatorname{logMAR}, P<0.001)$ and worse mean CRT $(390.8 \pm 145.79 \mu \mathrm{M}, \quad P=0.001)$ compared to responders. The mean changes in both BCVA and CRT at 3 and 6 months post-treatment from baseline among responders and non-responders were also significantly different $(P<0.05)$. No significant differences $(P>0.05)$ were observed between age and smoking status between the two groups (Table 4).

When the treatment response group was further analysed based on the genotypes for ARMS2 rs10490924, a significant difference was observed among the nonresponder group in mean changes of CRT at 6 months post-treatment with a highest increase of $97.3 \pm 128.36 \mu \mathrm{M}$

Table 3 Visual acuity and central retinal thickness outcome by genotype among nAMD subjects

\begin{tabular}{|c|c|c|c|c|c|c|c|c|c|}
\hline & & \multicolumn{4}{|c|}{ ARMS2 rs10490924 $(n=145)$} & \multicolumn{4}{|c|}{ HTRA1 rs11200638 $(n=145)$} \\
\hline & & $\overline{\mathrm{GG}}$ & GT & $\pi$ & $P$ & GG & GA & AA & $P$ \\
\hline Total $(n)$ & & $21(14.5)$ & $57(39.3)$ & $67(46.2)$ & & $19(13.1)$ & $47(32.4)$ & $79(54.5)$ & \\
\hline Mean age $(\text { years })^{a}$ & & $66.47 \pm 7.31$ & $70.35 \pm 7.74$ & $68.87 \pm 7.25$ & $0.122^{c}$ & $65.95 \pm 7.46$ & $69.87 \pm 7.79$ & $69.41 \pm 7.26$ & $0.137^{c}$ \\
\hline \multirow[t]{2}{*}{ Gender } & Male & $8(38.1)$ & $40(70.2)$ & $38(56.7)$ & & $6(31.6)$ & 37 (78.7) & $43(54.4)$ & \\
\hline & Female & $13(61.9)$ & $17(29.8)$ & $29(43.3)$ & $0.032^{c^{*}}$ & $13(68.4)$ & $10(21.3)$ & $36(45.6)$ & $0.001^{c^{*}}$ \\
\hline \multirow[t]{3}{*}{ Mean BCVA (logMAR) ${ }^{a}$} & Baseline & $0.59 \pm 0.28$ & $0.56 \pm 0.28$ & $0.56 \pm 0.25$ & $0.861^{\mathrm{b}}$ & $0.59 \pm 0.27$ & $0.62 \pm 0.28$ & $0.53 \pm 0.25$ & $0.190^{b}$ \\
\hline & $\begin{array}{l}3 \\
\text { months }\end{array}$ & $0.58 \pm 0.28$ & $0.58 \pm 0.26$ & $0.61 \pm 0.27$ & $0.771^{b}$ & $0.58 \pm 0.29$ & $0.61 \pm 0.27$ & $0.59 \pm 0.26$ & $0.906^{b}$ \\
\hline & $\begin{array}{l}6 \\
\text { months }\end{array}$ & $0.45 \pm 0.29$ & $0.58 \pm 0.28$ & $0.62 \pm 0.28$ & $0.046^{\mathrm{b} *}$ & $0.44 \pm 0.31$ & $0.58 \pm 0.27$ & $0.61 \pm 0.29$ & $0.044^{\mathrm{b} *}$ \\
\hline \multirow[t]{3}{*}{ Mean CRT $(\mu \mathrm{M})^{a}$} & Baseline & $\begin{array}{l}417.8 \pm \\
129.82\end{array}$ & $\begin{array}{l}388.7 \pm \\
143.95\end{array}$ & $\begin{array}{l}369.5 \pm \\
134.71\end{array}$ & $0.357^{c}$ & $\begin{array}{l}431.5 \pm \\
128.46\end{array}$ & $\begin{array}{l}393.9 \pm \\
151.47\end{array}$ & $\begin{array}{l}366.7 \pm \\
129.63\end{array}$ & $0.153^{c}$ \\
\hline & $\begin{array}{l}3 \\
\text { months }\end{array}$ & $\begin{array}{l}343.9 \pm \\
165.37\end{array}$ & $\begin{array}{l}355.3 \pm \\
131.49\end{array}$ & $353.6 \pm 93.17$ & $0.411^{b}$ & $\begin{array}{l}350.3 \pm \\
172.62\end{array}$ & $\begin{array}{l}357.9 \pm \\
128.46\end{array}$ & $\begin{array}{l}350.5 \pm \\
100.83\end{array}$ & $0.665^{b}$ \\
\hline & $\begin{array}{l}6 \\
\text { months }\end{array}$ & $\begin{array}{l}323.6 \pm \\
144.39\end{array}$ & $\begin{array}{l}339.0 \pm \\
129.48\end{array}$ & $\begin{array}{l}400.1 \pm \\
127.90\end{array}$ & $\begin{array}{l}< \\
0.001^{b *}\end{array}$ & $\begin{array}{l}329.2 \pm \\
150.19\end{array}$ & $\begin{array}{l}341.7 \pm \\
130.29\end{array}$ & $\begin{array}{l}387.5 \pm \\
129.89\end{array}$ & $0.008^{\mathrm{b} *}$ \\
\hline \multirow[t]{2}{*}{$\begin{array}{l}\text { Changes in BCVA } \\
\text { (logMAR) }^{a}\end{array}$} & $\begin{array}{l}3 \\
\text { months }\end{array}$ & $-0.01 \pm 0.21$ & $0.02 \pm 0.24$ & $0.05 \pm 0.19$ & $0.263^{b}$ & $-0.003 \pm 0.19$ & $-0.01 \pm 0.24$ & $0.06 \pm 0.21$ & $0.104^{b}$ \\
\hline & $\begin{array}{l}6 \\
\text { months }\end{array}$ & $-0.14 \pm 0.27$ & $0.03 \pm 0.28$ & $0.06 \pm 0.29$ & $0.011^{b *}$ & $-0.15 \pm 0.26$ & $-0.03 \pm 0.27$ & $0.08 \pm 0.29$ & $0.002^{b_{*}}$ \\
\hline \multirow[t]{2}{*}{ Changes in CRT $(\mu M)^{\text {a }}$} & $\begin{array}{l}3 \\
\text { months }\end{array}$ & $\begin{array}{l}-73.9 \pm \\
98.67\end{array}$ & $\begin{array}{l}-33.4 \pm \\
126.33\end{array}$ & $\begin{array}{l}-15.8 \pm \\
140.46\end{array}$ & $0.507^{c}$ & $\begin{array}{l}-81.2 \pm \\
101.09\end{array}$ & $\begin{array}{l}-36.1 \pm \\
113.17\end{array}$ & $\begin{array}{l}-16.1 \pm \\
143.46\end{array}$ & $0.141^{c}$ \\
\hline & $\begin{array}{l}6 \\
\text { months }\end{array}$ & $\begin{array}{l}-94.2 \pm \\
82.17\end{array}$ & $\begin{array}{l}-49.7 \pm \\
145.18\end{array}$ & $30.6 \pm 184.27$ & $0.022^{c *}$ & $\begin{array}{l}-102.4 \pm \\
82.16\end{array}$ & $\begin{array}{l}-52.3 \pm \\
145.09\end{array}$ & $20.8 \pm 178.85$ & $0.003^{\mathrm{c*}}$ \\
\hline
\end{tabular}

Data are presented as percentages in parentheses

$C R T$ central retinal thickness, BCVA best-corrected visual acuity

*Significant $P$ value, $P<0.05$

${ }^{a}$ Data presented as mean \pm standard deviation (SD)

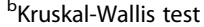

cMann-Whitney $U$ test 
Table 4 Visual acuity and central retinal thickness outcome by response to ranibizumab among nAMD subjects

\begin{tabular}{|c|c|c|c|c|}
\hline & & Responder $(n=54)$ & Non-responder $(n=91)$ & $p^{b}$ \\
\hline Age & & $68.33 \pm 6.47$ & $69.56 \pm 8.07$ & 0.343 \\
\hline Smoking & & $15(27.8)$ & $35(38.5)$ & 0.191 \\
\hline \multirow[t]{3}{*}{ Mean BCVA (logMAR) ${ }^{a}$} & Baseline & $0.66 \pm 0.27$ & $0.51 \pm 0.24$ & $0.001^{*}$ \\
\hline & 3 months & $0.57 \pm 0.29$ & $0.61 \pm 0.24$ & 0.304 \\
\hline & 6 months & $0.43 \pm 0.24$ & $0.67 \pm 0.28$ & $<0.001^{*}$ \\
\hline \multirow[t]{3}{*}{ Mean CRT $(\mu M)^{a}$} & Baseline & $480.3 \pm 153.78$ & $326.9 \pm 87.12$ & $<0.001^{C *}$ \\
\hline & 3 months & $348.0 \pm 114.79$ & $355.8 \pm 124.27$ & 0.642 \\
\hline & 6 months & $321.5 \pm 98.73$ & $390.8 \pm 145.79$ & $0.001^{*}$ \\
\hline \multirow[t]{2}{*}{ Changes in BCVA (logMAR) ${ }^{a}$} & 3 months & $-0.09 \pm 0.20$ & $0.10 \pm 0.19$ & $<0.001^{*}$ \\
\hline & 6 months & $-0.23 \pm 0.22$ & $0.16 \pm 0.23$ & $<0.001^{*}$ \\
\hline \multirow[t]{2}{*}{ Changes in CRT $(\mu M)^{a}$} & 3 months & $-132.3 \pm 133.05$ & $28.92 \pm 83.39$ & $<0.001^{C_{*}}$ \\
\hline & 6 months & $-158.9 \pm 132.02$ & $63.96 \pm 119.60$ & $<0.001^{C_{*}}$ \\
\hline
\end{tabular}

Data are presented as percentages in parentheses

$C R T$ central retinal thickness, BCVA best-corrected visual acuity

"Significant $P$ value, $P<0.05$

${ }^{a}$ Data presented as mean \pm standard deviation (SD)

${ }^{\mathrm{b}}$ Mann-Whitney $U$ test

'Student's $t$ test

among non-responders carrying the risk genotype $(P=$ 0.009). For HTRA1 rs11200638, the mean BCVA at 3 months post-treatment recorded a significantly worse BCVA among non-responders which carried the non-risk genotype $(0.90 \pm 0.20 \operatorname{logMAR}, P=0.034)$. A significant association was also observed in a regression analysis between the two response groups and genotypes for each polymorphism with the ARMS2 rs10490924 using a co-dominant model $(P<0.001)$ and HTRA1 rs11200638 using a recessive model $(P<0.001)$ (Table 5$)$.

\section{Gene expression analysis}

The levels of mRNA for the HTRA1 gene showed a significant difference between non-responders and responders for the homozygous non-risk GG genotype with the responders having a 15-fold higher expression of the HTRA1 gene compared to non-responders ( $P=$ $0.032)$. No significant difference was observed for the ARMS2 expression levels between the two response groups (Fig. 2).

\section{Discussion}

Over the years, an increasing number of biomarkers related to the development of nAMD have been discovered, and the most frequent findings are polymorphisms of the ARMS2 and HTRA1 genes. The heterogeneity in response to anti-VEGF treatment among nAMD patients has resulted in increasing pharmacogenetic studies on the association of possible high-risk biomarkers related to nAMD which respond to anti-VEGF treatment. Previously, we have investigated the pharmacogenetic response of $\mathrm{CFH} Y 402 \mathrm{H}$ polymorphism with ranibizumab therapy but reported no significant association among Malaysian subjects [24].

Aetiology of nAMD is known as a multifactorial disease caused by environmental and genetic factors [3]. Increasing age is known as the strongest risk factor associated with AMD [1, 3], followed by smoking [2]; this could also be why male gender is significant in the present study as most smokers are among the male subjects. Gender risk is inconsistent; there are studies reporting females at higher risk of $\operatorname{AMD}[3,25]$; however, there are also studies reporting males at higher risk $[26,27]$. The association of Chinese ethnicity in the present study is similar to the findings from Singapore, which also has a multi-ethnic population, that AMD was more common among the Chinese and Indian compared to Malays [27]. A recent finding from Malaysia also reported the Chinese had a significantly higher frequency of receiving ranibizumab treatment compared to Indians and Malays [28]. Furthermore, the Age-Related Eye Disease Study Research Group [29] and Vassilev et al. [30] similarly report an association between diabetes and hypertension with a risk of developing nAMD.

Despite the environmental factors, genetic factors, such as genetic polymorphisms of ARMS2 and HTRA1 genes, are commonly studied in relation to nAMD with significant findings in various populations, such as findings from northern China [19], India [31], Han Chinese [8], Israel [6] and Poland [32]. We also reported an association of complement factor $H$ gene [24, 33], VEGF+ 405 G/C [34] and complement factor 3 R102G [35] gene polymorphisms with AMD among Malaysians. A recent pharmacogenetic study on CFH rs1061170 among 
Table 5 Visual acuity and central retinal thickness outcome by response to ranibizumab and genotypes

\begin{tabular}{|c|c|c|c|c|c|c|c|c|c|}
\hline \multirow{2}{*}{\multicolumn{2}{|c|}{ ARMS2 rs10490924 }} & \multicolumn{4}{|c|}{ Responders $(n=54)$} & \multicolumn{4}{|c|}{ Non-responders $(n=91)$} \\
\hline & & $\mathrm{GG}(n=16)$ & $\mathrm{GT}(n=22)$ & $\Pi(n=16)$ & $p^{c}$ & $\mathrm{GG}(n=5)$ & $\mathrm{GT}(n=35)$ & $\Pi(n=51)$ & $p^{c}$ \\
\hline Age & & $66.68 \pm 7.88$ & $68.77 \pm 6.97$ & $69.38 \pm 3.70$ & 0.469 & $65.80 \pm 5.81$ & $71.34 \pm 8.12$ & $68.71 \pm 8.07$ & 0.187 \\
\hline Smoking & & $5(31.3)$ & $8(36.4)$ & $2(12.5)$ & 0.251 & $2(40.0)$ & $16(45.7)$ & $17(33.3)$ & 0.509 \\
\hline \multirow[t]{3}{*}{ Mean BCVA (logMAR) ${ }^{a}$} & Baseline & $0.58 \pm 0.27$ & $0.67 \pm 0.27$ & $0.72 \pm 0.28$ & $0.328^{b}$ & $0.64 \pm 0.35$ & $0.49 \pm 0.26$ & $0.51 \pm 0.22$ & $0.509^{b}$ \\
\hline & $\begin{array}{l}3 \\
\text { months }\end{array}$ & $0.51 \pm 0.25$ & $0.54 \pm 0.27$ & $0.67 \pm 0.36$ & 0.253 & $0.82 \pm 0.26$ & $0.61 \pm 0.25$ & $0.59 \pm 0.23$ & $0.191^{b}$ \\
\hline & $\begin{array}{l}6 \\
\text { months }\end{array}$ & $0.33 \pm 0.19$ & $0.48 \pm 0.26$ & $0.45 \pm 0.22$ & $0.119^{b}$ & $0.82 \pm 0.26$ & $0.65 \pm 0.28$ & $0.67 \pm 0.28$ & $0.420^{b}$ \\
\hline \multirow[t]{3}{*}{ Mean CRT $(\mu \mathrm{M})^{\mathrm{a}}$} & Baseline & $\begin{array}{l}432.7 \pm \\
107.73\end{array}$ & $490.5 \pm 159.19$ & $514.1 \pm 180.79$ & 0.307 & $\begin{array}{l}370.2 \pm \\
192.43\end{array}$ & $324.7 \pm 86.96$ & $324.1 \pm 73.19$ & 0.525 \\
\hline & $\begin{array}{l}3 \\
\text { months }\end{array}$ & $327.1 \pm 88.53$ & $367.3 \pm 138.55$ & $342.5 \pm 103.94$ & 0.562 & $397.8 \pm 320.3$ & $\begin{array}{l}347.8 \pm \\
128.34\end{array}$ & $357.1 \pm 90.37$ & $0.406^{b}$ \\
\hline & $\begin{array}{l}6 \\
\text { months }\end{array}$ & $307.7 \pm 85.37$ & $323.6 \pm 103.78$ & $332.3 \pm 108.36$ & 0.78 & $\begin{array}{l}374.4 \pm \\
269.59\end{array}$ & $\begin{array}{l}348.7 \pm \\
143.92\end{array}$ & $\begin{array}{l}421.4 \pm \\
127.03\end{array}$ & 0.072 \\
\hline \multirow[t]{2}{*}{$\begin{array}{l}\text { Changes in BCVA } \\
\left(^{\text {logMAR) }}{ }^{\mathrm{a}}\right.\end{array}$} & $\begin{array}{l}3 \\
\text { months }\end{array}$ & $-0.07 \pm 0.13$ & $-0.13 \pm 0.22$ & $-0.05 \pm 0.23$ & $0.462^{b}$ & $0.18 \pm 0.30$ & $0.12 \pm 0.21$ & $0.08 \pm 0.17$ & $0.651^{b}$ \\
\hline & $\begin{array}{l}6 \\
\text { months }\end{array}$ & $-0.24 \pm 0.16$ & $-0.19 \pm 0.24$ & $-0.26 \pm 0.23$ & 0.593 & $0.18 \pm 0.30$ & $0.16 \pm 0.21$ & $0.15 \pm 0.24$ & $0.960^{b}$ \\
\hline \multirow[t]{2}{*}{ Changes in CRT $(\mu \mathrm{M})^{\mathrm{a}}$} & $\begin{array}{l}3 \\
\text { months }\end{array}$ & $\begin{array}{l}-105.6 \pm \\
59.04\end{array}$ & $\begin{array}{l}-123.2 \pm \\
122.81\end{array}$ & $\begin{array}{l}-171.6 \pm \\
188.21\end{array}$ & 0.349 & $27.6 \pm 136.82$ & $23.1 \pm 92.01$ & $33.0 \pm 72.25$ & 0.865 \\
\hline & $\begin{array}{l}6 \\
\text { months }\end{array}$ & $\begin{array}{l}-125.0 \pm \\
52.98\end{array}$ & $\begin{array}{l}-166.8 \pm \\
135.36\end{array}$ & $\begin{array}{l}-181.8 \pm \\
176.76\end{array}$ & 0.454 & $4.2 \pm 85.65$ & $23.9 \pm 94.53$ & $97.3 \pm 128.36$ & $0.009^{*}$ \\
\hline Logistic regression $^{d}$ & \multicolumn{2}{|c|}{ Co-dominant $^{e}$} & \multicolumn{3}{|c|}{$P<0.001^{*}, \mathrm{OR}=3.15,95 \% \mathrm{Cl}(1.75-5.67)$} & & & & \\
\hline HTRA1 rs11200638 & & $\mathrm{GG}(n=15)$ & $\mathrm{GA}(n=21)$ & $\mathrm{AA}(n=18)$ & & $\mathrm{GG}(n=4)$ & $\mathrm{GA}(n=26)$ & $\mathrm{AA}(n=61)$ & \\
\hline Age & & $66.53 \pm 8.13$ & $68.95 \pm 7.07$ & $69.11 \pm 3.66$ & 0.455 & $63.75 \pm 4.11$ & $70.62 \pm 8.39$ & $69.49 \pm 8.04$ & 0.286 \\
\hline Smoking & & $4(26.7)$ & $9(42.9)$ & $2(11.1)$ & 0.087 & $2(50.0)$ & $13(50.0)$ & $20(32.8)$ & 0.284 \\
\hline \multirow[t]{3}{*}{ Mean BCVA $(\log M A R)^{a}$} & Baseline & $0.55 \pm 0.25$ & $0.69 \pm 0.28$ & $0.69 \pm 0.27$ & $0.192^{b}$ & $0.73 \pm 0.34$ & $0.55 \pm 0.26$ & $0.48 \pm 0.22$ & $0.180^{\mathrm{b}}$ \\
\hline & $\begin{array}{l}3 \\
\text { months }\end{array}$ & $0.49 \pm 0.25$ & $0.58 \pm 0.29$ & $0.62 \pm 0.33$ & 0.521 & $0.90 \pm 0.20$ & $0.63 \pm 0.25$ & $0.58 \pm 0.23$ & $0.034^{\mathrm{b} *}$ \\
\hline & $\begin{array}{l}6 \\
\text { months }\end{array}$ & $0.32 \pm 0.19$ & $0.48 \pm 0.26$ & $0.46 \pm 0.22$ & $0.059^{b}$ & $0.90 \pm 0.20$ & $0.67 \pm 0.25$ & $0.65 \pm 0.29$ & $0.191^{b}$ \\
\hline \multirow[t]{3}{*}{ Mean CRT $(\mu \mathrm{M})^{\mathrm{a}}$} & Baseline & $444.7 \pm 99.74$ & $487.1 \pm 168.15$ & $502.1 \pm 174.90$ & 0.556 & $\begin{array}{l}382.0 \pm \\
220.09\end{array}$ & $318.8 \pm 80.19$ & $326.7 \pm 77.79$ & 0.406 \\
\hline & $\begin{array}{l}3 \\
\text { months }\end{array}$ & $332.4 \pm 88.99$ & $380.5 \pm 141.31$ & $323.2 \pm 94.33$ & 0.251 & $\begin{array}{l}417.5 \pm \\
366.34\end{array}$ & $\begin{array}{l}339.7 \pm \\
116.68\end{array}$ & $\begin{array}{l}358.6 \pm \\
102.01\end{array}$ & $0.519^{b}$ \\
\hline & $\begin{array}{l}6 \\
\text { months }\end{array}$ & $313.4 \pm 85.14$ & $333.1 \pm 109.14$ & $314.6 \pm 100.66$ & 0.794 & $\begin{array}{l}388.3 \pm \\
309.23\end{array}$ & $\begin{array}{l}348.7 \pm \\
146.94\end{array}$ & $\begin{array}{l}408.9 \pm \\
130.38\end{array}$ & 0.212 \\
\hline \multirow[t]{2}{*}{$\begin{array}{l}\text { Changes in BCVA } \\
\left(^{(\text {logMAR })^{\mathrm{a}}}\right.\end{array}$} & $\begin{array}{l}3 \\
\text { months }\end{array}$ & $-0.05 \pm 0.10$ & $-0.12 \pm 0.23$ & $-0.08 \pm 0.23$ & $0.735^{b}$ & $0.18 \pm 0.36$ & $0.08 \pm 0.20$ & $0.10 \pm 0.18$ & $0.870^{b}$ \\
\hline & $\begin{array}{l}6 \\
\text { months }\end{array}$ & $-0.23 \pm 0.16$ & $-0.22 \pm 0.25$ & $-0.24 \pm 0.22$ & 0.945 & $0.18 \pm 0.35$ & $0.12 \pm 0.18$ & $0.17 \pm 0.24$ & $0.664^{b}$ \\
\hline \multirow[t]{2}{*}{ Changes in CRT $(\mu \mathrm{M})^{\mathrm{a}}$} & $\begin{array}{l}3 \\
\text { months }\end{array}$ & $\begin{array}{l}-112.3 \pm \\
54.30\end{array}$ & $\begin{array}{l}-106.6 \pm \\
115.37\end{array}$ & $\begin{array}{l}-178.9 \pm \\
183.41\end{array}$ & 0.191 & $35.5 \pm 156.67$ & $20.9 \pm 73.19$ & $31.9 \pm 83.25$ & 0.846 \\
\hline & $\begin{array}{l}6 \\
\text { months }\end{array}$ & $\begin{array}{l}-131.3 \pm \\
48.17\end{array}$ & $\begin{array}{l}-154.0 \pm \\
135.01\end{array}$ & $\begin{array}{l}-187.5 \pm \\
171.50\end{array}$ & 0.474 & $6.3 \pm 98.75$ & $29.9 \pm 91.8$ & $82.3 \pm 128.03$ & 0.107 \\
\hline Logistic regression $^{d}$ & \multicolumn{2}{|c|}{ Recessive $e^{e}$} & \multicolumn{7}{|c|}{$P<0.001^{*}, \mathrm{OR}=4.42,95 \% \mathrm{Cl}(2.11-9.25)$} \\
\hline
\end{tabular}



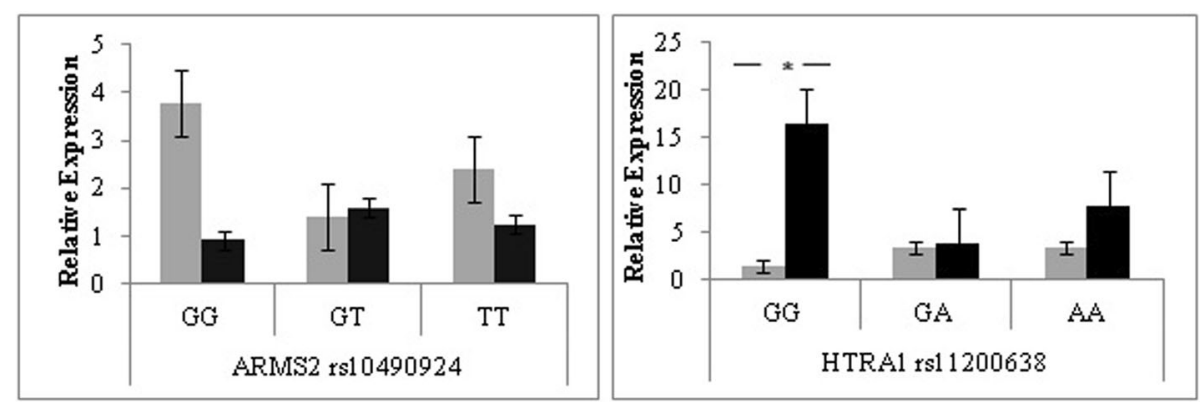

Fig. 2 Relative expression levels of ARMS2 and HTRA1 gene variant among responders $(n=20)$ and non-responders $(n=20)$ determined by the $\triangle \triangle C$ c calculation. a mRNA levels according to ARMS2 rs10490924 genotype. b mRNA levels according to HTRA1 rs11200638 genotypes. A significant difference was only observed between responder and non-responder groups for homozygous non-risk GG genotype of HTRA1 rs11200638 $(P=0.032)$. Bars, relative expression \pm standard error mean. Light bars, responder group. Dark bars, non-responder group

Malaysians reported no significant association with response to ranibizumab therapy [24]. In the present study, a significant association of ARMS2 rs10490924 and HTRA1 rs11200638 gene polymorphisms was reported among the nAMD patients. Since both ARMS2 rs104909 24 and HTRA1 rs11200638 gene polymorphisms have increasing reports of being associated with nAMD susceptibility, this led us to further investigate the relation of these polymorphisms with the heterogeneity response of nAMD patients to the ranibizumab treatment.

In this study, the response to ranibizumab was measured with regard to both anatomical (CRT) and functional (BCVA) aspects in correlation with ARMS2 rs1049 0924 and HTRA1 rs11200638 gene polymorphisms. To further evaluate the variable response to ranibizumab, the nAMD subjects were categorised into responders and non-responders based on the BCVA and CRT outcomes. There were also previous studies that measure the treatment outcome by categorising the subjects by their response to treatment; however, there was no uniformity and it could be one of the reasons for the conflicting findings on nAMD pharmacogenetic studies [36].

A significant association was reported after a logistic regression analysis in the present study between the two treatment response groups and the ARMS2 rs10490924 and HTRA1 rs11200638 polymorphisms, suggesting that the variable response to treatment might be affected by changes in the 10q26 chromosome biomarkers [7, 23]. These findings are further supported by the previous studies which reported that the risk allele ARMS2 rs10490924 and HTRA1 rs11200638 polymorphism was associated with a poor response to ranibizumab based on changes in BCVA [21, 37-39] and CRT [40]. However, the distribution of the HTRA1 rs11200638 alleles in the present study were not consistent with HWE among the nAMD groups which reasons could be due to HTRA1 rs11200638 as being strongly associated with risk of nAMD among Asian populations [17]. The nAMD group in the present study was comprised of
Malaysian subjects only and might explain the deviation from HWE.

Higher mean changes in CRT was observed at 6 months post-treatment among non-responders with homozygous risk ARMS2 rs10490924 TT genotype ( $P=$ 0.009 ) compared to non-responders with the normal genotype that have a smaller mean change in CRT. This suggests that subjects carrying the homozygous risk ARMS2 rs10490924 TT genotype are more likely to not respond to ranibizumab treatment compared to those with normal genotypes. These findings are consistent with previous studies such as those in Korea [17], Australia [39] and Poland [32]. However, there are also contradictory findings whereby the association of ARMS2 rs10490924 with ranibizumab response was not observed [7, 23], even in major studies, such as the IVAN study [41] and CATT trial [42]. The underlying discrepancies in this contradictory finding could be related to several aspects such as the differences in the treatment regimen of the patients. The present study only included patients receiving a treat and extend regimen of ranibizumab whereas the IVAN and CATT study included both monthly and pro re nata regimen treatment groups in their pharmacogenetic analysis. Second, the ethnic differences could result in the different associations as the present study included only Malaysians and findings from a Population Architecture using Genomics and Epidemiology study reported that risk associations of $C F H$ rs1061170 and ARMS2 rs10490924 in Europeans did not generalise to the non-European populations [43]. Findings from a large study conducted in India reported variants that were associated with AMD in the Western populations; the variants of $\mathrm{CFH}, \mathrm{C} 2$ and complement factor $B$ were contradictory with findings in India. Furthermore, the variants in ARMS2 and HTRA1 genes were found to be associated with increased risk of AMD in the INDEYE study, but not in the Western populations, which further suggests the effect of ethnic differences in AMD polymorphism studies [31]. 
Similarly, the non-responder group between HTRA1 rs11200638 genotypes also showed a significant difference, but only on mean BCVA at 3 months posttreatment with normal GG genotype $(0.90 \pm 0.20$ $\log M A R)$ having the worse mean BCVA compared to risk AA genotype $(0.58 \pm 0.23 \log M A R, P=0.034)$. This contradicts the ARMS2 rs10490924 findings, as the non-responders with the worst visual acuity were among the subjects carrying the risk genotype of ARMS2 rs10490924. This could be because the mean baseline BCVA was initially worse among subjects with HTRA1 rs11200638 GG genotypes. However, the risk AA genotypes reported a higher loss of BCVA from the baseline compared to the normal GG genotype which did not lose further vision at 6 months post-treatment.

It is suggested that the response to treatment could also be affected by the baseline vision, due to a phenomenon known as the ceiling effect, whereby subjects with a worse baseline BCVA were less likely to lose further vision and subjects with better BCVA were less likely to improve [44, 45]. This has also been observed in large studies, including the MARINA [46] and ANCHOR [47] studies which reported that the baseline BCVA is a strong predictor of treatment response. The poor baseline BCVA was also reported to be related with sub-retinal fluid thickness at baseline and these subjects had a greater possibility of gaining vision compared with subjects that had a better BCVA at baseline [48]. The UK Age-Related Macular Degeneration EMR Users Group was also in accordance with the present findings as they reported that those with a better baseline VA had a mean drop of six letters lost; however, those with a worse baseline VA only had a mean loss of three letters by 52 weeks post-treatment [49].

Due to the strong linkage disequilibrium among the ARMS2 and HTRA1 genes, it remains unclear which variants are at higher risk of nAMD pathogenesis; thus, the correlation of ARMS2 and HTRA1 variants to ranibizumab treatment response remains unclear. However, studies are suggesting that the risk allele might lead to changes in transcriptional activity and, thus, affect the proteins normal activity resulting in a differing response to the ranibizumab treatment [21].

In the present study, since we observed significant associations between ARMS2 rs10490924 and HTRA1 rs11200638 polymorphisms in response to ranibizumab and the strong linkage disequilibrium among the two variants, we further investigated the mRNA levels of both variants among the two treatment response groups. A significant association was only observed in the mRNA expression of HTRA1 rs11200638 GG genotype with the non-responders having the highest HTRA1 expression compared to the responders. The high expression of HTRA1 GG genotype was also reported by Yang et al. [10] and DeWan et al. [9] in a study between AMD and healthy controls whereby the AMD subjects had a higher expression of HTRA1. The overexpression of HTRA1 has been related to the alteration of Bruch's membrane, resulting in the invasion of the extracellular matrix with choroid capillaries and inhibition of the angiogenesis and extracellular matrix deposition regulator $(T G F-\beta)$ [10]. Thus, the worse BCVA and high thickness of CRT among the GG genotypes of non-responders in the present study could be related to the overexpression of HTRA1 genes resulting to the poor response to the ranibizumab treatment.

The present study focused on a targeted SNP analysis of ARMS2 and HTRA1 genes due to the high risk of rs10490924 and rs11200638 polymorphisms with development of nAMD and their significant association with response to ranibizumab therapy such as reported in China [19], Korea [50] and Spain [7]. The SNPs were selected based on its functional significance to the heterogeneous response to ranibizumab, the location of the SNPs and a minor allele frequency of more than $10 \%$ as suggested by Pettersson et al. [51] and Tabangin et al. [52] in the selection of SNPs for genetic association studies.

\section{Study limitations}

Despite the findings reported in this study, there are limitations that should be taken into consideration. The study design itself is a limitation as this is an unmatched comparative case-control study. A matched case-control study is advantageous in controlling cofounders that could alter the exposure and outcome relationship in an analysis. However, the present study with an unmatched case-control could better examine the impact of the cofounders and further provide evidence on significant risk factors related to nAMD. The lack of CNV subtypes is one of the major limitations as performing analysis based on the CNV subtypes (predominantly classic $\mathrm{CNV}$, minimally classic $\mathrm{CNV}$ and occult $\mathrm{CNV}$ ) could provide more specific information on which CNV is related with the different response to ranibizumab. A short follow-up period of 6 months post-treatment is also a limitation due to time constraint in the present study. Although the small sample size is a significant sample size for a two-centre study in a Malaysian population, future studies could be conducted in a larger sample size in multiple centres around Malaysia to confirm the pharmacogenetic findings. Furthermore, the variable criteria in grouping the responders/good response and non-responders/poor response to the ranibizumab treatment could also be one of the factors affecting the pharmacogenetic results, as there are contradictory findings in previous studies. The present study only focused on two variants of ARMS2 and HTRA1 genes which do not exclude the possibility of other variants in the two genes or in other 
high-risk genes (CFH, VEGFA and C3) or even a combined effect of the polymorphisms that might play a role in the heterogenous response to ranibizumab therapy. Future studies could also sequence other rare variants in the high-risk genes and this might provide a more depth information on pharmacogenetic associations of nAMD.

\section{Conclusions}

A significant association was observed between ARMS2 rs10490924 and HTRA1 rs11200638 polymorphisms in response to the ranibizumab treatment among nAMD subjects. An overexpression of mRNA in the HTRA1 GG genotype was also reported and could contribute to the non-responders' reaction to ranibizumab. Despite the reported data, future studies are needed to confirm the findings with a larger sample size and more stringent criteria which accounts for the limitations of the present study.

\section{Materials and methods}

This study was approved by Universiti Putra Malaysia (UPM), Universiti Kebangsaan Malaysia (UKM) ethics committee and Medical Research Ethics Committee (MREC), Ministry of Health, Malaysia (MOH). This study was registered with the National Medical Research Registry with the registration number NMRR-14-1176-21475.

\section{Data collection}

A prospective cohort study was conducted from September 2014 to February 2016 in ophthalmology clinics at two tertiary centres, Universiti Kebangsaan Malaysia Medical Centre (UKMMC) and Hospital Selayang. A total of 145 nAMD subjects were selected as case subjects from a total of 158 nAMD subjects, as the remaining 13 subjects failed at follow-up. Informed consent was obtained from all the subjects prior to starting the study.

\section{Patient's criteria}

All subjects underwent comprehensive ophthalmologic examinations, including BCVA test by Snellen chart, fluorescein angiography (FA) and central retinal thickness analysis using optical coherence tomography (OCT). The subjects were then diagnosed as nAMD by ophthalmologists at each centre based on the clinical examinations performed. None of the subjects were previously treated for nAMD.

All subjects were aged above 50 years old with confirmed presence of exudation involving macula and a follow-up appointment of 6 months after the first injection of ranibizumab (Lucentis; Novartis Pharma AG, Basel, Switzerland and Genentech Inc., South San Francisco, California, USA). They were eligible for this study.
Subjects who do not fulfil the mentioned inclusion criteria and had a CNV secondary to other causes, such as inflammatory diseases, trauma, hereditary diseases, pathologic myopia, angioid streaks, other retinal diseases other than AMD and eyes previously submitted to posterior vitrectomy were excluded from this study.

\section{Control's criteria}

Control subjects with no previous history of nAMD, absence of other retinal disorders except mild cataract, no visual impairment and no family history of nAMD were recruited in both centres during routine ophthalmic examination. Subjects with severe cataracts were excluded from control subjects.

\section{Measures of response to treatment}

Socio-demographic factors, medical history, smoking history and the complications of nAMD were retrieved from the medical records of the subjects. Each nAMD subject received $0.5 \mathrm{mg} / 0.05 \mathrm{ml}$ ranibizumab per intravitreal injection following the treat and extend regimen and was followed up for 6 months. The BCVA and central retinal thickness (CRT) at baseline and 6 months were compared and evaluated with regard to the treatment. Those with an improvement of three lines or greater in the Snellen chart and/or a resolution of more than $100 \mu \mathrm{M}$ decrease in CRT at 6 months post-treatment compared to baseline were regarded as responders, while the non-responders had no improvements.

\section{Gene and SNP selection}

Based on the obtained literature reviews, HTRA1 rs1120 0638 and ARMS2 rs10490924 gene polymorphisms were among the significantly associated variants with response to ranibizumab therapy in nAMD and, thus, were selected as a candidate SNP in the present study. Furthermore, the SNP was selected based on the functional significance, location and minor allele frequency of more than $10 \%$. HTRA1 rs11200638 and ARMS2 rs10490924 have a minor allele frequency of 0.241 and 0.255 , respectively, as reported by the National Center of Biotechnology Information (NCBI).

\section{DNA extraction and genotyping}

Peripheral blood was collected from all the subjects and the genomic DNA was extracted using a QIAamp DNA blood mini kit (Qiagen, Valencia, California, USA) and stored at $-20^{\circ} \mathrm{C}$ for further analysis. The genotyping of the HTRA1 rs11200638 and ARMS2 rs10490924 gene polymorphisms was performed using the polymerase chain reaction-restriction fragment length polymorphism (PCR-RFLP) method. The PCR amplification was performed in a thermocycler (Thermo Fisher Scientific, 
Waltham, MA, USA) with a total volume of $25 \mu \mathrm{l}$ for each polymorphism, including the following primers: forward: 5' -ATGCCACCCACAACAACTTT-3' and reverse: 5'-CGCGTCCTTCAAACTAATGG-3' for HTR A1 rs11200638 polymorphism and forward: 5'-TACC CAGGACCGATGGTAAC-3' and reverse: 5' - GAGG AAGGCTGAATTGCCTA-3' for ARMS2 rs10490924 polymorphism. Genomic DNA amplification was performed for 35 cycles of denaturation at $95^{\circ} \mathrm{C}$ for $30 \mathrm{~s}$, annealing at $57^{\circ} \mathrm{C}$ (HTRA1 rs11200638), $52^{\circ} \mathrm{C}$ (ARMS2 rs10490924) for $30 \mathrm{~s}$ and extension at $72{ }^{\circ} \mathrm{C}$ for $45 \mathrm{~s}$, followed by the final extension at $72{ }^{\circ} \mathrm{C}$ for $5 \mathrm{~min}$.

The amplified product of HTRA1 rs11200638 (385-bp fragment) and ARMS2 rs10490924 (449-bp fragment) was then digested with the EagI (rs11200638) and PvuII (rs10490924) restriction enzymes (New England Biolabs, Beverly, MA, USA) at $37^{\circ} \mathrm{C}$ for $3 \mathrm{~h}$. The digested products were separated on $2 \%$ agarose gels and visualised using the UV alpha imager (Alpha Innotech, San Leandro, California). Random samples were chosen to validate the results, and identical results were obtained.

\section{RT-PCR and quantitative real-time PCR}

From the 145 nAMD subjects recruited, 20 responders and 20 non-responders to ranibizumab treatment were randomly selected to evaluate the mRNA expression of the HTRA1 and ARMS2 genes. Total RNA was isolated from whole blood samples using the Tempus Spin RNA Isolation Reagent Kit (Applied Biosystems, California, USA). The cDNA synthesis was then conducted using the QuantiTect Reverse Transcription Kit (Qiagen, Valencia, California, USA). Following the synthesis of cDNA, quantitative real-time PCR was performed with the QuantiNova SYBR Green PCR Kit (Qiagen, Valencia, California, USA) using the MiniOpticon Real-time PCR System (Bio-rad Hungary Ltd) to evaluate the level of gene expression for the HTRA1 and ARMS2 genes. The primers for HTRA1 expression assay were forward: $5^{\prime}-\mathrm{C}$ GGAAGATGGACTGATCGTGAC-3 and reverse: 5'-G GTGATGGCTTTTCCTTTGGC-3' and the primers for ARMS2 expression assay were forward: 5'-GATGGC AAGTCTGTCCTCCT-3' and reverse: 5'-TTGCTGCA GTGTGGATGATAG-3'. The housekeeping gene, $\beta$ actin, was used as an endogenous control in the normalisation of each sample. The samples were prepared in triplicate in a final volume of $20 \mu \mathrm{l}$ with real-time PCR conditions at $95^{\circ} \mathrm{C}$ for $3 \mathrm{~min}$ followed by 40 cycles of 95 ${ }^{\circ} \mathrm{C}$ for $10 \mathrm{~s}$ and $51{ }^{\circ} \mathrm{C}$ for $1 \mathrm{~min}$ and a florescence measurement. The relative gene expression was determined by a $\Delta \Delta$ Ct calculation.

\section{Statistical analysis}

The logarithm of the minimal angle of resolution (logMAR) was derived from the BCVA recorded in the
Snellen eye examination chart for further statistical analysis. The Hardy-Weinberg equilibrium and linkage disequilibrium were verified using Haploview software. Data on normal continuous variables was compared using Student's $t$ test and one-way analysis of variance (ANOVA), and skewed continuous variables were compared using the Mann-Whitney $U$ test and KruskalWallis test whereas categorical variables were compared using the chi-square test. Furthermore, a logistic regression analysis was performed to determine the association between genetic variants of HTRA1 rs11200638 and ARMS2 rs10490924 to ranibizumab treatment. All statistical analyses were performed using SPSS version 21.0 (SPSS Inc., Chicago, IL, USA), and $P<0.05$ was considered to be statistically significant.

\section{Acknowledgements}

The authors would like to extend their gratitude to Hospital Selayang and UKMMC and all the volunteers involved in this study.

\section{Funding}

This study was supported by Putra Grant from Universiti Putra Malaysia (Grant No: 9409800 and 9432700). All authors have no financial disclosures relevant to this article.

\section{Availability of data and materials}

All data generated or analysed during this study are included in thus published article.

\section{Authors' contributions \\ NAM and VR designed and conducted the study. NAM, VR, NFN and HMI contributed to the collection and management. NAM, VR, HMI, CSM, HFK, CYM, WAWS and MHM contributed to the preparation and review. All authors agreed to submit the final manuscript.}

\section{Ethics approval and consent to participate}

This study was approved by Universiti Putra Malaysia (UPM), Universiti Kebangsaan Malaysia (UKM) ethics committee and Medical Research Ethics Committee (MREC), Ministry of Health, Malaysia $(\mathrm{MOH})$. This study was registered with the National Medical Research Registry with the registration number NMRR-14-1176-21475.

\section{Consent for publication}

Not applicable.

\section{Competing interests}

The authors declare that they have no competing interests.

\section{Publisher's Note}

Springer Nature remains neutral with regard to jurisdictional claims in published maps and institutional affiliations.

\section{Author details}

${ }^{1}$ Malaysian Research Institute on Ageing, Universiti Putra Malaysia, 43400 Serdang, Selangor DE, Malaysia. ${ }^{2}$ Department of Ophthalmology, Universiti Kebangsaan Malaysia Medical Centre, 56000 Cheras, Kuala Lumpur, Malaysia.

${ }^{3}$ Department of Nutrition and Dietetics, Faculty of Medicine and Health Sciences, Universiti Putra Malaysia, 43400 Serdang, Selangor DE, Malaysia. ${ }^{4}$ Department of Ophthalmology, Hospital Selayang, Lebuhraya Selayang-Kepong, 68100 Batu Caves, Malaysia. ${ }^{5}$ Department of Family Medicine, Faculty of Medicine and Health Sciences, Universiti Putra Malaysia, 43400 Serdang, Selangor DE, Malaysia. ${ }^{6}$ Department of Medicine, Faculty of Medicine and Health Sciences, Universiti Putra Malaysia, 43400 Serdang, Selangor DE, Malaysia. ${ }^{7}$ Department of Surgery, Faculty of Medicine and Health Sciences, Universiti Putra Malaysia, 43400 Serdang, Selangor DE, Malaysia. 


\section{Received: 15 November 2018 Accepted: 17 February 2019} Published online: 22 February 2019

\section{References}

1. Lim LS, Mitchell P, Seddon JM, Holz FG, Wong TY. Age-related macular degeneration. Lancet. 2012;379:1728-38.

2. Velilla S, Garcia-Medina JJ, Garcia-Layana A, Dolz-Marco R, Pons-Vazquez S, Pinazo-Duran MD, et al. Smoking and age-related macular degeneration: review and update. J Ophthalmol. 2013;2013:895147.

3. Lambert NG, ElShelmani H, Singh MK, Mansergh FC, Wride MA, Padilla M, et al. Risk factors and biomarkers of age-related macular degeneration. Prog Retin Eye Res. 2016;54:64-102.

4. Yasuda M, Kiyohara Y, Hata Y, Arakawa S, Yonemoto K, Doi Y, et al. Nineyear incidence and risk factors for age-related macular degeneration in a defined Japanese population the Hisayama study. Ophthalmology. 2009;116: 2135-40.

5. Cheung CM, Laude A, Yeo I, Tan SP, Fan Q, Mathur R, et al. Systemic, ocular and genetic risk factors for age-related macular degeneration and polypoidal choroidal vasculopathy in Singaporeans. Sci Rep. 2017;7:41386.

6. Chowers I, Meir T, Lederman M, Goldenberg-Cohen N, Cohen Y, Banin E, et al. Sequence variants in HTRA1 and LOC387715/ARMS2 and phenotype and response to photodynamic therapy in neovascular age-related macular degeneration in populations from Israel. Mol Vis. 2008;14:2263-71.

7. Cruz-Gonzalez F, Cabrillo-Estevez L, Rivero-Gutierrez V, Sanchez-Jara A, De Juan-Marcos L, Gonzalez-Sarmiento R. Influence of CFH, HTRA1 and ARMS2 polymorphisms in the response to intravitreal ranibizumab treatment for wet age-related macular degeneration in a Spanish population. Int J Ophthalmol. 2016:9:1304-9.

8. Liang XY, Lai TY, Liu DT, Fan AH, Chen LJ, Tam PO, et al. Differentiation of exudative age-related macular degeneration and polypoidal choroidal vasculopathy in the ARMS2/HTRA1 locus. Invest Ophthalmol Vis Sci. 2012;53: 3175-82.

9. Dewan A, Liu M, Hartman S, Zhang SS, Liu DT, Zhao C, et al. HTRA1 promoter polymorphism in wet age-related macular degeneration. Science. 2006:314:989-92.

10. Yang Z, Camp NJ, Sun H, Tong Z, Gibbs D, Cameron DJ, et al. A variant of the HTRA1 gene increases susceptibility to age-related macular degeneration. Science. 2006;314:992-3.

11. Wang G, Dubovy SR, Kovach JL, Schwartz SG, Agarwal A, Scott WK, et al. Variants at chromosome 10q26 locus and the expression of HTRA1 in the retina. Exp Eye Res. 2013;112:102-5.

12. Tosi GM, Caldi E, Neri G, Nuti E, Marigliani D, Baiocchi S, et al. HTRA1 and TGF-beta1 concentrations in the aqueous humor of patients with neovascular age-related macular degeneration. Invest Ophthalmol Vis Sci. 2017:58:162-7.

13. Kanda A, Chen W, Othman M, Branham KE, Brooks M, Khanna R, et al. A variant of mitochondrial protein LOC387715/ARMS2, not HTRA1, is strongly associated with age-related macular degeneration. Proc Natl Acad Sci U S A. 2007;104:16227-32.

14. Moja L, Lucenteforte E, Kwag KH, Bertele V, Campomori A, Chakravarthy U, et al. Systemic safety of bevacizumab versus ranibizumab for neovascular age-related macular degeneration. Cochrane Database Syst Rev. 2014;9: CD011230.

15. Solomon SD, Lindsley K, Vedula SS, Krzystolik MG, Hawkins BS. Anti-vascular endothelial growth factor for neovascular age-related macular degeneration. Cochrane Database Syst Rev. 2014:8:CD005139.

16. Ba J, Peng RS, Xu D, Li YH, Shi H, Wang Q, et al. Intravitreal anti-VEGF injections for treating wet age-related macular degeneration: a systematic review and meta-analysis. Drug Des Devel Ther. 2015;9:5397-405.

17. Park UC, Shin JY, McCarthy LC, Kim SJ, Park JH, Chung H, et al. Pharmacogenetic associations with long-term response to anti-vascular endothelial growth factor treatment in neovascular AMD patients. Mol Vis. 2014:20:1680-94.

18. Kloeckener-Gruissem B, Barthelmes D, Labs S, Schindler C, Kurz-Levin M, Michels $\mathrm{S}$, et al. Genetic association with response to intravitreal ranibizumab in patients with neovascular AMD. Invest Ophthalmol Vis Sci. 2011;52:4694-702.

19. Xu Y, Guan N, Xu J, Yang X, Ma K, Zhou H, et al. Association of CFH, LOC387715, and HTRA1 polymorphisms with exudative age-related macular degeneration in a northern Chinese population. Mol Vis. 2008;14:1373-81.
20. Ratnapriya R, Chew EY. Age-related macular degeneration-clinical review and genetics update. Clin Genet. 2013:84:160-6.

21. Yuan D, Liu X, Yuan S, Xie P, Liu Q. Genetic association with response to intravitreal ranibizumab for neovascular age-related macular degeneration in the Han Chinese population. Ophthalmologica. 2013;230:227-32.

22. Ding $X$, Patel $M$, Chan CC. Molecular pathology of age-related macular degeneration. Prog Retin Eye Res. 2009;28:1-18.

23. Orlin A, Hadley D, Chang W, Ho AC, Brown G, Kaiser RS, et al. Association between high-risk disease loci and response to anti-vascular endothelial growth factor treatment for wet age-related macular degeneration. Retina. 2012;32:4-9.

24. Mohamad NA, Ramachandran V, Ismail P, Mohd Isa H, Chan YM, Ngah NF, et al. Analysis of the association between $\mathrm{CFH} Y 402 \mathrm{H}$ polymorphism and response to intravitreal ranibizumab in patients with neovascular agerelated macular degeneration (nAMD). Bosn J Basic Med Sci. 2018;18:260-7.

25. Age-Related Eye Disease Study Research Group. Risk factors associated with age-related macular degeneration. A case-control study in the age-related eye disease study: Age-Related Eye Disease Study Report Number 3. Ophthalmology. 2000;107:2224-32.

26. Kawasaki R, Wang JJ, Aung T, Tan DT, Mitchell P, Sandar M, et al. Prevalence of age-related macular degeneration in a Malay population: the Singapore Malay Eye Study. Ophthalmology. 2008;115:1735-41.

27. Cheung CM, Li X, Cheng CY, Zheng Y, Mitchell P, Wang JJ, et al. Prevalence, racial variations, and risk factors of age-related macular degeneration in Singaporean Chinese, Indians, and Malays. Ophthalmology. 2014;121:1598-603.

28. Mohamad NA, Ramachandran V, Ismail P, Mohd Isa H, Chan YM, Ngah NF, et al. Prevalence and treatment patterns of ranibizumab and photodynamic therapy in a tertiary care setting in Malaysia. Int J Ophthalmol. 2017;10: 1889-97.

29. Clemons TE, Milton RC, Klein R, Seddon JM, Ferris FL 3rd. Risk factors for the incidence of Advanced Age-Related Macular Degeneration in the AgeRelated Eye Disease Study (AREDS) AREDS report no. 19. Ophthalmology. 2005;112:533-9.

30. Vassilev ZP, Ruigomez A, Soriano-Gabarro M, Garcia Rodriguez LA. Diabetes, cardiovascular morbidity, and risk of age-related macular degeneration in a primary care population. Invest Ophthalmol Vis Sci. 2015;56:1585-92.

31. Sundaresan $P$, Vashist $P$, Ravindran RD, Shanker A, Nitsch D, Nonyane BA, et al. Polymorphisms in ARMS2/HTRA1 and complement genes and agerelated macular degeneration in India: findings from the INDEYE study. Invest Ophthalmol Vis Sci. 2012;53:7492-7.

32. Teper SJ, Nowinska A, Wylegala E. A69S and R38X ARMS2 and Y402H CFH gene polymorphisms as risk factors for neovascular age-related macular degeneration in Poland - a brief report. Med Sci Monit. 2012;18:PR1-3.

33. Bakri NM, Ramachandran V, Kee HF, Subrayan V, Isa H, Ngah NF, et al. Association of copy number variations in complement factor $\mathrm{H}$-related genes among age-related macular degenerative subjects. The Kaohsiung J Med Sci. 2017;33:602-8.

34. Mohamad NA, Ramachandran V, Ismail P, Mohd Isa H, Chan YM, Ngah NF, et al. VEGF polymorphisms among neovascular age-related macular degenerative subjects in a multiethnic population. Genet Test Mol Biomarkers. 2017;21:600-7.

35. Mohamad NA, Ramachandran V, Ismail $P$, Isa HM, Chan YM, Ngah NF, et al. R102G polymorphism of the complement component 3 gene in Malaysian subjects with neovascular age-related macular degeneration. Egypt J Med Hum Genet. 2017;19:77-81.

36. Shah AR, Williams S, Baumal CR, Rosner B, Duker JS, Seddon JM. Predictors of response to intravitreal anti-vascular endothelial growth factor treatment of age-related macular degeneration. Am J Ophthalmol. 2016;163:154-66 e8.

37. McKibbin M, Ali M, Bansal S, Baxter PD, West K, Williams G, et al. CFH, VEGF and HTRA1 promoter genotype may influence the response to intravitreal ranibizumab therapy for neovascular age-related macular degeneration. $\mathrm{Br} J$ Ophthalmol. 2012;96:208-12

38. Smailhodzic D, Muether PS, Chen J, Kwestro A, Zhang AY, Omar A, et al. Cumulative effect of risk alleles in CFH, ARMS2, and VEGFA on the response to ranibizumab treatment in age-related macular degeneration. Ophthalmology. 2012;119:2304-11.

39. Abedi F, Wickremasinghe S, Richardson AJ, Islam AF, Guymer RH, Baird PN. Genetic influences on the outcome of anti-vascular endothelial growth factor treatment in neovascular age-related macular degeneration. Ophthalmology. 2013;120:1641-8. 
40. Kitchens JW, Kassem N, Wood W, Stone TW, Isernhagen R, Wood E, et al. A pharmacogenetics study to predict outcome in patients receiving anti-VEGF therapy in age related macular degeneration. Clin Ophthalmol. 2013;7:1987-93.

41. Lotery AJ, Gibson J, Cree AJ, Downes SM, Harding SP, Rogers CA, et al. Pharmacogenetic associations with vascular endothelial growth factor inhibition in participants with neovascular age-related macular degeneration in the IVAN study. Ophthalmology. 2013;120:2637-43.

42. Hagstrom SA, Ying GS, Pauer GJ, Sturgill-Short GM, Huang J, Callanan DG, et al. Pharmacogenetics for genes associated with age-related macular degeneration in the Comparison of AMD Treatments Trials (CATT). Ophthalmology. 2013;120:593-9.

43. Restrepo NA, Spencer KL, Goodloe R, Garrett TA, Heiss G, Buzkova P, et al. Genetic determinants of age-related macular degeneration in diverse populations from the PAGE study. Invest Ophthalmol Vis Sci. 2014;55:6839-50.

44. Pedrosa AC, Sousa T, Pinheiro-Costa J, Beato J, Falcao MS, Falcao-Reis F, et al. Treatment of neovascular age-related macular degeneration with antiVEGF agents: predictive factors of long-term visual outcomes. J Ophthalmol. 2017;2017:4263017.

45. Finger RP, Wickremasinghe SS, Baird PN, Guymer RH. Predictors of anti-VEGF treatment response in neovascular age-related macular degeneration. Surv Ophthalmol. 2014;59:1-18.

46. Boyer DS, Antoszyk AN, Awh CC, Bhisitkul RB, Shapiro H, Acharya NR. Subgroup analysis of the MARINA study of ranibizumab in neovascular agerelated macular degeneration. Ophthalmology. 2007;114:246-52.

47. Kaiser PK, Brown DM, Zhang K, Hudson HL, Holz FG, Shapiro H, et al. Ranibizumab for predominantly classic neovascular age-related macular degeneration: subgroup analysis of first-year ANCHOR results. Am J Ophthalmol. 2007;144:850-7.

48. Regillo CD, Busbee BG, Ho AC, Ding B, Haskova Z. Baseline predictors of 12month treatment response to ranibizumab in patients with wet age-related macular degeneration. Am J Ophthalmol. 2015;160:1014-23 e2.

49. Collaborators. The neovascular age-related macular degeneration database: multicenter study of 92976 ranibizumab injections: report 1: visual acuity. Ophthalmology. 2014;121:1092-101.

50. Kang HK, Yoon MH, Lee DH, Chin HS. Pharmacogenetic influence of LOC387715/HTRA1 on the efficacy of bevacizumab treatment for agerelated macular degeneration in a Korean population. Korean J Ophthalmol. 2012;26:414-22.

51. Pettersson FH, Anderson CA, Clarke GM, Barrett JC, Cardon LR, Morris AP, et al. Marker selection for genetic case-control association studies. Nat Protoc. 2009:4:743-52.

52. Tabangin ME, Woo JG, Martin $L J$. The effect of minor allele frequency on the likelihood of obtaining false positives. BMC Proc. 2009;3:S41.

\section{Ready to submit your research? Choose BMC and benefit from:}

- fast, convenient online submission

- thorough peer review by experienced researchers in your field

- rapid publication on acceptance

- support for research data, including large and complex data types

- gold Open Access which fosters wider collaboration and increased citations

- maximum visibility for your research: over $100 \mathrm{M}$ website views per year

At BMC, research is always in progress.

Learn more biomedcentral.com/submissions 